Portland State University

PDXScholar

1975

\title{
A Study to Differentiate Between Runaways and Non-runaways Among Juveniles Reported Missing
}

Neil E. Crannell

Portland State University

Patricia A. Hoffman

Portland State University

Follow this and additional works at: https://pdxscholar.library.pdx.edu/open_access_etds

Part of the Social Work Commons

Let us know how access to this document benefits you.

\section{Recommended Citation}

Crannell, Neil E. and Hoffman, Patricia A., "A Study to Differentiate Between Runaways and Non-runaways Among Juveniles Reported Missing" (1975). Dissertations and Theses. Paper 1779.

https://doi.org/10.15760/etd.1778

This Thesis is brought to you for free and open access. It has been accepted for inclusion in Dissertations and Theses by an authorized administrator of PDXScholar. Please contact us if we can make this document more accessible: pdxscholar@pdx.edu. 


\title{
A STUDY TO DIFFERENTIATE BETWEEN RUNAWAYS AND NON-RUNATAYS AMONG JUVENIIES REPORTED MISSING
}

\author{
By \\ PATRICTA A . HOFFMAN \\ NEIL E. CRANNEIL, \\ A report submitted in partial fulfillment of \\ the requirements for the degree of \\ MASTER OF \\ SOCIAL WORK

\section{Portland State University} \\ 1975
}


To the Office of Graduate Studies:

The faculty advisor approves the practicum of Patricia Hoffman and Neil Cramnel presented May 27, 1975. 
The research group wishes to acknowledge the following individuals :

Dr. Quentin Clarkson, Associate Professor and Practicum Advisor, who provided his services as a consultant to the research group throughout the entire research study.

Lt. Dennis Brand, Supervisor of the Youth Services of the Multnomah County Sheriff's Office, who provided direction, expertise, and support throughout the project.

Ms. Sidney Jones, Intake Worker for the Sheriff's Youth Services, for her insight and assistance in this study.

Ms. Sandi Magedanz for her diligence in typing the final study. 
Page

ACKNOWLEDGEMENTS. .................. . i i

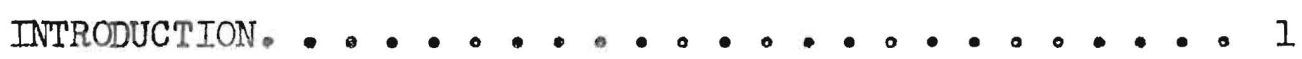
ITTERATURE REVIEW ........ .........

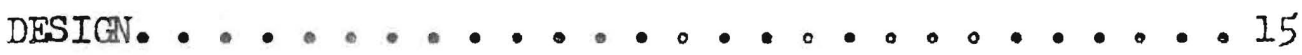

STRA GEGY. . . . . . . . . . . 16

SELECTION OF SAMPLE . . . . . . . . . . 17

WITIINGNESS TO PARTICIPATE IN STUDY . . . . . . 18

DEVELOPMENT OF THE TNSTRUMENT •......... 19

THE INSTRUMENT. . . . . . . . . . . . . . 21

SUMARY: DEVELOPMENT OF THE INSTRUMEIVT 。. . ...26 PRESENTATION AND INTERPRETATION OF DATA •. •.... 28

PRESENTATION OF DATA. . . . . . . . . . 29

SUIMARY OF RESEARCH FINDTNGS. . . . . . . . LI

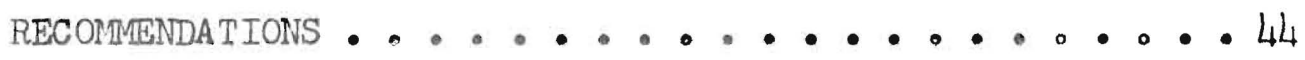




\section{INTRODUCTION}

The need for the project described in this paper was first expressed to the researchers by Lt. Dennis Brand of the MuItnomah County Sheriff's Youth Services Section. He and those officers in the Youth Services had noted not only an increasing number of reported runaways nationally but also locally in recent years. With limited manpower the follow-up of reportedly missing juveniles was often very minimal. In other parts of the country in the last few years various juveniles who had been reported as missing and who were presumed to be runaways were later found dead. When police officers then checked the child's background many did not fit the patterm of a runaway juvenile. It was also discovered that frequently no follow-up had been undertaken by the police agency concerning the child other than the taking of the initial missing juvenile report. On the basis of the above information, the increasing numbers of runaways reported to the Multnomah County Sheriff's Office (as indicated in the statistics presented in the following paragraphs) and the need expressed by the Youth Services officers for a more efficient method of following-up missing juveniles, including distinguishing which cases require immediate investigation, this project was undertaken.

According to Oregon law (ORS 419.470 ) running away is a status offense and is considered within the jurisdiction of the juvenile 
court system:

The juvenile court has exclusive original jurisdiction in any case involving a person who is under 18 years of age and ...(f) who has run away from home.

Simply defined, a runaway is an individual under 18 years of age who has left his or her home without the consent or knowledge of a parent or guardian. For the exclusive interests of this project, munaways were normally away from home for at least 24 hours and had been reported to the Missing Persons Section of the Multnomah County Sheriff's Youth Services.

The sertousness of the runaway problem in Multnomah County is illustrated in the statistics from a recent report on manays in Multnomah County which shows that in 1967, 17.3 percent (III9 juveniles) of all delinquency referrals to the Juvenile Court were manaws and by 1971 this had increased to 24.3 percent (1965 juveniles) were munaways. This figure represented the most frequent reason for court referral of any act. ${ }^{1}$ From December 1973 through February 1974 a total of 257 juveniles were reported missing to the Multnomah County Sheriff's Youth Services. Among those missing there were 174 girls and 83 boys. Of the 257 , 145 returmed home in less than one week. By March 15, 1974, 223 were cleared (their whereabouts were known) out of the 257 total. During 1974 there were 889 missing juveniles investigated by the Multnomah County Sheriff's Office, of these 534 were cleared.

It is the purpose of this research project to develop a profile of predictive variables that would be helpful in distinguishing a 
missing juvenile report of a runaway from that of a missing youth who may have met with "foul play" and who does not fit the patterm of the runaway youth. The usefulness of such a tested set of predictive variables would be in designing a report form to be used by the peace officer who takes the initial report enabling him to immediately identify the situation as one of a runaway indicating one type of follow-up as opposed to a situation involving the possibility of "foul play" which would indicate a totally different investigative procedure and priority of action. 


\section{CHA PTER I}

\section{LITERATURE REVIEW}

Running away is becoming an increasingly common phenomena among the youth in our society as a whole. A ten year study conducted by the New York City Police Department (1950-60) showed a 51 percent increase of runaways corresponding with a decrease of 1.4 percent in the population of the city from which the sample was drawn. The study further revealed that 70 percent of all delinquents have mun away at some time. In over 75 percent of the 262 cases used in the study parents reported that they knew of no valid reason that had caused the child to run away. ${ }^{2}$

As mentioned in the introduction, it is essential to differentiate in the missing jurenile category between a runaway and a non-munaway. It is therefore necessary to identify certain predictive factors that precipitate runaway behavior which could be viewed when investigating the report of a missing juvenile. Since it is important that the factors be those that are currently influencing munay behavior, recent literature was most closely examined to determine what current writers perceive as causal factors influencing manay behavior. Before the 1960's. Many researchers on runaways in the 1930's and $1940^{\prime}$ 's attributed such behavior to personal conflicts that the child could not solve in some other way. Armstrong viewed munning awey as a psychoneurotic response which she felt was accompanied by 
mental deficiency and poor impulse control.3 Riemer believed that runaways had a severe "narcissistic disorder" or, at least, an "extremely negative character."l The belief that muning away is motivated by surging Dedipal conflicts which the juvenile can only solve by physical separation from the parent was held by Rosenheim. 5

Other researchers like Outland explained that running away was nothing more than a youthful search for adventure, 6 while Balser went so far as to state it was a positive step in problem-solving.? This position was later supported by Paull who concluded that an adolescent's "developing sense of self-hood and independence may be constructivaly expressed in the course of the runaway escapade." 8 For a more thorough review of the literature conceming runaway behavior prior to the $1960^{\prime} \mathrm{s}$ see the research study by Greer, Hertlein, and Regner listed in the bibliography.

Reasons for running. James Hildebrand $(1963)^{9}$ in a study of 262 runaway cases in Brooklyn, New York, attempted to determine the age distribution of runaways, recidivist patterns, length of time missing and factors impelling a child to run. The broad motivating factors which he found influencing a child to run included a poor home environment, family discipline, school problems, mental illness, and sexual activity (including getting married, becoming pregnant, or leaving to live with a member of the opposite sex).

Hildebrand's study found that ages 8-12 of both sexes left primarily due to poor home environments. From ages 13-15, family discipline conflicts and school difficulties characterized by truancy, 
poor grades and misconduct at school wer the greatest contributing factors. In the age range 15-17 most were girls who had a combination of a poor home environment and a sex-related problem. There appeared to be a low incidence of mental disorder as a contributing factor for a significant number of runaways.

The patterm of recidivism for boys showed a steady increase from age 12 to a peak at age 15 with a significant decrease thereafter. In the girls' group from age 14 the incidence gradually increased with age. Although up to age 12 both sexes were absent one day or less, from age 13 and up age increase and time spent away from home showed a positive correlation that is, the older the child, the more likely the child is to stay away longer and the longer the child stays away, the higher the likelihood of recidivism.

In a later study by Hildebrand $(1963)^{10}$ he examined the runaway problem in two New York City Police Precincts, one a low-income and high-crime area and the other a relatively quiet middle-income residential area. His study found that there was a close parallel between runaway rates and the incidence of crime in these areas. The runaway rate in the high crime area was more than twice the city rate and about six times the rate of a middle income residential nefghborhood. Children in the high crime area began running away at a significantly earlier age (10 as opposed to 12). The factors influencing juveniles in this study were family instability, neighborhood deterioration, low income and economic dependency and low level of education. Of these factors Hildebrand stated that "the 
attitude of the parent or guardian concerming the importance of education is a prime factor in the vast majority of these cases."II The main argument of the study is that the incidence of crime and delinquency varies with the socio-economic condition of the area not simply because more affluent members of society are successful. in evading the law but because the conditions in a substandard neighborhood are more conducive to delinquent behavior. A high correlation of the 6 percent runaway increase and the 8 percent delinquency increase for that city was emphasized.

Delinguency or pathology. In an intensive study on runaways by Robert Shellow, et. al. $(1967)^{12}$ several factors relevant to the study of Multnomah County manaways are mentioned. To eliminate a bias they saw in previous studies whereby running away was designated either as an act of delinquency or as a result of personal psychopathology depending on whether the agency involved wes a correctional institution, a mental health facility or welfare services, the researchers chose a sample from a general group -776 juveniles reported missing to the police over a period of one year. The researchers personally contacted the juveniles and their parents. Their research showed among other things that a greater proportion of runaways had broken homes than did non-runaways. School difficulties were more evident with the runaways, for example, truancy, low grades, and being retained in a grade. The authors cautioned that it is often difficult to designate clear cut differences between manaws and non-runaways since a deciding factor may be the 
immediate circumstances of his situation influencing him to mun away. The researchers did separate the runaway population into two groups. The group of the chronic runaways included those for whom "running away was intimately bound up with individual and family pathology. "I3 The second group which included mainly those who had run away once, resembled the non-runaway group rather than the first group. In two-thirds of the runaway cases the juvenile was missing less than 48 hours. On this basis if a juvenile resembles the nonmanaway group and is gone much more than 48 hours, the possibility of foul play strongly exists.

Runaway girls and family conflict. Research on manaways completed by Robey, et.al. (1964) I4 $^{14}$ involved 42 middle-class adolescent girls and their families who were referred to a Court Clinic for treatment and psychiatric evaluation. They were part of 162 manaw girls out of a total of 293 girls brought before the court during a ten year period. The girls' ages ranged from 13 to 17 years; the mean age was 15 years and three months. The researchers reported observing a "consistent patterm of family interaction that we feel is basic to the etiology of muning away."15 The pattern they described included a disturbed marital relationship, inadequate control by the parents over their own and the girl's impulses, and deprivation of the love of her mother who subtly pressured the girl to assume the maternal role. This she handles well until adolescence at which time she develops an attitude of rebellion against her role and runs away. The family interaction around which the dynamics revolved according 
to the researchers was a threatened unconscious incestuous relationship with the father incited by the mother. Subsequent acting out of the unresolved Oedipal conflict through running away represents an attempted solution. They concluded that running away is the result of a "complex neurotic interaction between the parents and the daughter in a triangle situation, and its seriousness as a symptom calls for far greater concern than is presently given by most parents and law enforcement officials."16

Parent-child relationship. Randall Foster (1962)17 explored runaway behavior utilizing a sample of 100 individuals with a history of running away from home and 75 juveniles without such a history. These groups consisted of juveniles referred for counseling to a psychiatric clinic by a Los Angeles Juvenile Court. In the runaway sample the incidence of running away in delinquent boys was 34.7 percent and delinquent girls 64.2 percent. The groups were compared on the basis of "individual and intrafamilial factors" in the following three main areas: general data including any academic or behavior problems; parent-child relationships especially parent-child separation; and information concerning the runaway activity of the experimental group.

The results revealed that of the 100 runaway subjects 91 had a history of parent-child separation and 9 did not; of the 75 control subjects 40 had such a history and 30 did not. Parent-child separation was defined as the presence of a history of parent-child separation for over one month. The most frequent report of 
separation involved the absence of the father before the child was five years without the subsequent return of the parent. Absence of the father in general accounted for 60 percent of all parentchild separations. There was a significantly greater incidence of step- and adoptive parents among the male runaway group including 37 step- or adoptive parents and 11 had not. In the control group 15 had step- or adoptive parents and 16 had not. Some of the characteristics that showed a much greater incidence in the experimental subjects' families were physical aggression, open sexual activity in the home, more family mobility and a marked rejection of the child by the parents. Also the presence of stepor adoptive parents correlates with running away as a symptom of the child. The runaways exhibited a Iimited ability to express aggressive impulses in a socially acceptable manner. Delinquent acts which were much more frequent among muaways than among non-runaways in the study were auto theft, hetero-sexual activity recorded only among girls, and truancy which was twice as frequent as among the non-munaways. Reasons most frequently given for running were punishment from or arguments with parents. In concluding the writeup of his study Foster stated that the

loss of a parent or the presence of a substitute parent is not in itself sufficient to determine this symptom. Nor is an intact family a gua rantee that a child will not run away. These disturbances in the family stmucture rather appear to interact with other factors, such as the degree of parental rejection and the extent of overt aggression or sexual promiscuity in the home, in the formation of this symptom.18

Self-reporting. In an attempt to discover explanations for mu- 
away behavior, Goldmeier and Dean (1973)19 focused their research on 57 runaways and 68 non-runaways. Questionnaires were sent to each person in the study to gather information describing how the individuals saw their problem-solving capacities, their ability to get along in school academically and with teachers and peers, their feelings about their families and how they think their families feel about them, and how supportive they considered selected persons in their environment.

The findings revealed that many runaways were from homes where one natural parent was absent. In contrast to non-munaways concerning school, teachers, and academic achievement, runaways reported less interest, greater difficulty getting along and poorer grades. About 75 percent of the runaways stated they seldom or never felt at ease in their home compared to only 6 percent of the non-manaways. When in trouble the runaways manifested a greater tendency to turn to their peers rather than to the adults in their environment whereas non-runaways indicated an ability to relate to a variety of adults. The results of this study indicate that the runaways were affected by certain situational stresses that impaired their functioning and influenced them to seek support from peers rather than the family or the school.

Inmer control. Levanthal (1964)20 researched the inner controluncontrol of manays and the relationship between their control over inner events and control over outer events. The experimental sample consisted of 42 munaways (ages 5-17 with a median age of 13.5 years). 
The control group was composed of 42 non-munaways drawn from a child guidance clinic of the same age and sex division (27 boys and 15 girls) as the munaway group. Levanthal developed a scale for rating manifestations of uncontrol in each group. Ilis criteria for uncontrol were: discharge-type behavior such as tantrums, impulsivity, and enuresis; deficient behavior-regulating mechanisms such as poor judgment; and a self-image of being helpless and unable to control.21

The results showed that runaways manifested more uncontrol than the nonmrunaway comparison cases in every area. Frequent behaviors in the runaway group showing uncontrol included impulsivity, direct aggression, aggressive fantasies, expression of need for affection, demanding behavior, jealousy, problems in excretory control, and a tendency to express their sexual drive behaviorally. Levanthal stressed that the danger for the runaway is of "ego loss" for when such a threat is imminent, intense and desperate actions may occur such as running away.

Runaway experience. In a study by Howell, Emmons, and Frank $(1973)^{22}$ in Boston, 41 adolescents ( 18 girls and 23 boys; mean age 15) who had sought assistance at a street clinic for runaways were interviewed by telephone at least a year after they had run away. The study sought to answer questions about the quality of life for runaways prior to running, after returning home and the experience of being "on the run." The sample was limited to adolescents who had been missing for at least three days and who were from two- 
parent "stable" families (described by child interviewed as not troubled by parental quarreling, alcohol or drug abuse, or child abuse).

The results revealed that everyone of the sample described difficulties with parents, school or both existing before they ran away. Relationships with fathers were significantly more troubled for both sexes than were their relationships with their mother. Over half of the group (25) felt their parents did not respect them as individuals, did not allow them sufficient autonomy and did not take them "seriously." School problems before muning were reported by 52 percent of the girls and 44 percent of the boys. Boys reported significantly more personal drug or alcohol use (12 boys or 52 percent) than did girls ( 3 or 17 percent). It was pointed out in this study that many of the adolescent respondents seem to have chosen to run away as a self-determined approach to the resolution of family conflict.

After returning home the majority ( 74 percent of the boys and 86 percent of the girls) reported their lives to be much better. An improvement in their relationship with their fathers was indicated by 54 percent, while 80 percent saw an improvement in their relationship with their mothers. Boys reported improvement in their relationship with their fathers significantly more than did girls.

In reflecting on the runaway experience itself 60 percent of the boys and 72 percent of the girls stated they felt the experience had been a positive one. They are, however, reluctant to recommend it 
to others (only 11 percent of the boys and 17 percent of the girls said they would recommend it).

Summary. In reviewing the reasons proposed for adolescents running away it is apparent that numerous reasons have been suggested. The variety includes lack of inner control, depression, fear of rejection by a parent, incestuous fears, reaction to an undesirable home situation and an attempt to assert independence. The current literature indicates that difficulties within the family situation are more often the cause of running away than the individual psychopathology of the adolescent. Also evident from the literature is that it is not possible to decide upon one specific determinant of running away but it is most likely that the reasons for such behavior vary within certain defined limits from adolescent to adolescent. It does appear though that many of the findings show that there often is a breakdown in the family communication system which, of course may be produced by various factors. 


\section{CHÁPTER II}

\section{DESIGN}

Researchers were approached by Lt. Dennis Brand of the Multnomah County Sheriff's Office, Youth Services Section requesting a study in Multnomah County that would facilitate more efficient follow-up procedures on juvenile missing person reports processed through the Jurenile Section. He was specifically concerned with developing a report form for the officer responding to the call that would contain questions that would determine immediately whether the missing youth would be classified as a runaway or might be classified as a missing person and possible victim of "foul play".

It was then hypothesized that through an extensive review of the current literature on recent research on maways that a questionnaire could be developed and administered to an experimental group of families of runaways and to a control group drawn from the same age group of youths residing in the geographic area of the experimental group.

We tried to gather a third sample of "verified foul play victims" to compare the other with. By going to the homicide division of Multnomah County, Washington County, Clackamas County and Clark County in Washington (a.1 areas immediately surrounding the Portland area) we were only able to come up with 10 samples that fit our sample criteria. We decided that this was not a wide nough sample to be 
significant. We had hypothesized that our control group of nonrunaways would more closely resemble the profile of the "foul play victim" than that of the runaway. Since we could not get a sufficient sample we discarded these data.

Objectives: To discover predictive variables as to who might be a runaway and who might be a victim of "foul play"。

Product: The development of a Police Report Form that will enable the responding officer to determine immediately whether the missing person is a runaway or a possible victim of foul pley. Since the investigative follow-up is quite different in both cases, this would provide more efficient use of the officer's time and better service to the community.

Process: In-home interviews of parents of youths in Multnomah County. A questionnaire would be developed by the researchers and filled out by the researchers during the interviews. Youths represented in the sample would be in the 12-17 year old age bracket. An examination of the comparison and experimental groups would hopefully develop statistically-based predictive variables established from differences in group response.

STRA TEGY

We decided upon the use of a short questionnaire to be administered to an experimental group of 80 parents of youths that had been reported missing to the Juvenile section. This sample would be taken randomly from reports received and processed over the past 5 months. A comparison group would then be selected of youths in the County 
that were non-munaways. The parents of these young people would then be administered the same questionnaire. We decided upon inhome personal interviews scheduled at such a time as to assure that both parents could be present for the administering of the questionnaire. This was done to further assure reliability of honest response. We decided to use an official letter of introduction signed by the Sheriff (see Appendices) explaining the purpose of the study and asking citizen cooperation in the study so that the Sheriff's Office might better serve the community in services and follow-up.

It was decided that one researcher would be responsible for the data collection on the comparison group and the other would be responsible for data collection on the experimental group. SELECTION OF SAMPLE

Experimental Group: Sheriff's Office records revealed that $76 \%$ of the youths reported missing came from the section of the county clustering around and within the David Douglas High School District (N.E. 72nd through N.E. 165th primarily) of the Portland School District. There was an average of 80 youths reported missing each month during our sample period of April 1974 through November 1974. We drew our sample from ten families representing each of the eight months randomly selected from the David Douglas a rea mentioned above.

Twenty of the experimental group sample were taken from chronic munaweys that were currently institutionalized. This was done with 
the cooperation of the institution by reviewing the personal files of the subjects. The subjects were selected by the same criteria mentioned above. (They too had been reported missing to the Juvenile Section during the sample period.) The subjects were all females.

It was further decided to use as a sample base youths between the ages of 12 and 16 and twice the number of females as males as they represented the population from which the sample was drawn. (Youths reported missing to the Sheriff's Office during the sample period.) No appointments were made ahead of time.

Comparison Group: The sample was randomly selected from the student body of David Douglas High School in Multnomah County. David Douglas High School has a student population of 1251 students in the upper division (grades $11-12$ ) and 1411 students in the lower division (grades 9-10). It was decided to draw 150 names from the list of students. As in the experimental group, approximately twice the number of girls were selected as were boys.

The random sample was selected through extracting every 17 th name from the upper division and by extracting every 19 th name from the lower division.

There was a slight change in strategy in the comparison group. The school administrators requested that the researcher telephone the parents ahead in order to give them an opportunity to decline to grant an interview.

WILLTNGNESS TO PARTICIPATE IN THE STUDY

Experimental Group: One person refused to be interviewed stating 
that the Sheriff's Office did not give him good service and he was not going to help them in any way。

Comparison Group: In this group 10 refused to cooperate in the study. Reasons for this refusal are uncertain although from the reactions of those called, it seemed that the impersonalness of a phone call hindered communication and heightened suspicion. Some refused when the Sheriff's Office was mentioned.

The overall response was good. One of the biggest problems the researcher had in the experimental group was limiting the interview time. Those interviewed were generally pleased to have the opportunity to participate in the study and very anxious to talk with the researcher about the manaw.

\section{DEVEUOPMENT OF THE INSTRUMENT}

The development of the instmument came from two sources. The primary source was the literature review. The selection of relevant date was determined through the information gained in interviews with Sidney Jones, (munaway intake worker at the Multnomah County Sheriff's office) whose primary job is to record all manaway reports and assist in clearing them by contacting the families of the missing youth to see if they have heard from the subject. (It is not uncommon for a youth to return home and for the parents to fail to notify the Sheriff's Office to close the case.) Ms. Jones gave input from a background of four years of interacting with the parents of runaways. The Sheriff's Office was of further assistance by arranging for the researcher dealing with the experimental group 
to Interview officers in the Youth Services Section and uniform officers on the road who had extensive experience with runaways. The researcher was also able to "ride along" with officers responding to runaway calls enabling her to seo first hand the difficulty in determining the investigative follow-up necessary for each missing juvenile call. 
The theoretical base of the literature and the practical knowledge gathered from the agency lead to the development of the instriment gathering the following basic information:

\section{Parent Information:}

A. Ages: This element was felt important due to the general response by the intake worker who found that a large number of young people roported as missing persons seemed to come from families where the parents were remarkably young to have adolescent children or were over 50. This was not previously researched in the literature. There was no uniform agency data with which to check this out. Where this information was furnished, it was incomplete as only the age of the person reporting the youth missing was recorded.

B. Residence: This related to type of residence, house or apartment. This question had no statistical basis. The officers interviewed felt that "kids living in apartments seem to get into more trouble than kids living in houses." We decided to test their hypothesis as well as considering the factor of "personal 
space" (assuming that a house might afford one more room than an apartment) as being a predictor for "running away".

C. Employment: To test the hypothesis that a number of youngsters min because of financial and psychological stress within the family when the hoad of household is out of work, this element was included. This was first considered relevant as a result of the research mentioned in the article "Reasons for Runaways" (American Journal of Psychiatry) which indicates that income, unemployment and family attitude toward education are relevant factors.

D. Marital Status: Statistical results in the Multnomah County munaway study by Susan Greer, et. 2l. revealed that 65 percent of the control group (taken from Cleveland $\mathrm{High}$ ) in the study were from natural families or currently separated families, compared to only 27 percent of chronic munaways coming from natural or separated family units. The study also showed that 44 percent of all runaways came from an intact family unit with natural parents.

E. Family Constellation: The Creer study showed that 85 percent of the non-runaway control group were living with one or both of their parents as compared to 44 percent of the runaway group living with one or both 
of their natural parents. We felt it important to retest this in our questionnaire since this could be a high predictor as to who might be a runaway.

F. Educational Level: Due to the fact that our experimental sample is drawn from those persons reported as missing to the Sheriff's Office, this may be significant in determining which educational level reports their child as missing to a public agency most frequently. We felt this was relevant also due to Hildebrand's findings in "Reasons for Runaways" showing that the parental attitude was a cructal factor in the majority of runaway cases in the high crime area when educational level and inc orne were low.

G. Income Level: Same reasons as the above.

H. Parent's Attitudes Toward Child's Sexual Habits: This is again a retesting of hypothesis stated in the articles in the literature review. Hildebrand's research findings ("Why Ruraways Leave Home") showed that girls between the ages of 15 and 17 ran due to poor home environment and sexual problems (pregnancy, a boy friend, or a threatening father). Similar results were found by Robey, et. al. in "The Runaway: A Reaction to Family Stress." 
I. Prolonged Early Separation From a Natural Parent: Foster, in his articlo, "Intrapsychic and Environmental Factors in Running Away From Home", found that in his sample of 100 munaways, 91 had a history of parent-child separation. The most frequently occurring incidence of early separation was of father-child before the child was five years of a ge.

J Family Stress: Informally, it had been observed by the officers interviewed and by Sidney Jones that the family seemed under undue stress at the time the youth was reported missing. We decided to test this by listing several possible stresses within the past year that the family might have encountered. Those included were: birth of a new child, death in the family, financial problems, legal problems, psychiatric problems (Including alcoholism), a move to a new school district, divorce and remarriage.

K. Have Other Family Members Run Away As Juveniles?: This question was to test the general family attitude toward muning away. It was felt this might be relevant particularly if one child had mun in the past or that it might set a standard for future acting out in this manner by the same child or other members. 
2. Runaway Information:

A. Age and Crade in School: Here we were testing the youth's school performance. All the runaway literature refers to school problems as being significant in the runaway groups. Hildebrand ranked it second in the leading causes for youths running away. Leventhal's article, "Inner Control Deficiencies in Runaway Children" was especially significant showing a lack of inner control in his runaway sample paired with frequent trouble in school. His study mentioned hyperactivity as one specific symptom of lack of inner control. We included a question as to whether the child had been treated medically for this condition.

B. Social Isolation: We developed several questions to check the youth's basic involvement with others through school and church. We further asked how he or she got along with others including family mernbers and whether the parents could name at least three of the youth's friends. Since adolescence is a time of heavy group identification and peer interaction, we felt this might be relevant. When the child was reported missing to the Sheriff's Office, it was rare that the parents could name more than one of the child's close friends. This may 
aga in be due to the parents interacting with a police agency. We decided to check this out in the questionnaire.

C. History of Antisocial Behavior: We were interested to see if the runaway youth is more involved with drugs, truancy, dismuptive behavior and rule breaking in school and had if the youth had more general involvement with the police than was experienced by the comparison group of non-runaways.

D. Chronic Runaway Episodes and Length of Time on the Run: We decided to ask the number of times a child had mun in the past and the length of time he remained away from home. This again related to Hildebrand's findings that recidivism trends can be based on age and duration of time that lapses before the youth returms home. We felt that his findings (that the older the youth was, the more likely he was to stay away for a longer duration and the Ionger he stayed away the more likely that he would run again) may have some important predictive value.

SUMMARY: DEVELOPMENT OF THE INSTRUMENT

The instrument was based on the relevant findings of previous research on runaways as well as practical experience gathered by interviewing Missing Person intake worker Sidney Jones, and officers experienced in working with runaway and "foul play" investigations. 
It was further based on the personal observations of the research as a "ride along" with officers responding to missing juvenile calls.

The instrument was administered to parents and foster parents of munaways and non-munaways in a specific age group (12-17). The sample was drawn from a specific area of Multnomah County (East County) showing a high rate of runaways duxing tho eight month sample period of April through November of 197/. The questionnaire asked primarily demographic information and specific social information on the munay and non-munaway.

The hypothesis was that there are several questions that will show a significant statistical difference in the responses of the comparison (non-munaway) group and the experimental (runaway) group. Out of these specific responses one might therefore develop predictive variables as to who might be a runaway and who might not fit that profile and therefore be a possible victim of "foul play". The end product will hopefully produce the data necessary to develop a better report form for officers responding to take a missing juvenile report and to insure better follow-up. 
CHAPTER IV

PRESENTATION AND INTERPRETATION OF DATA

\section{Discriminant Analysis:}

In keoping with the stated purpose of the study, discriminant analysis was used. The subjects were divided into two groups, a runaway group and a comparison group of youths from the same geographic area and demographic make-up who had not run away. By administering the same questionnaire to the families of both groups we hypothesized that there would be a statistically significant difference in the responses of the two groups to the same questions, and further, that these responses would be good discriminators between the two groups. The end product of these statistically signifj.cant discriminators would then be the development of a report form to be tested by the Sheriff's Office. This form would enable the person receiving the missing person report to be able to immediately determine be asking key questions whether the youth reported missing fits a manaway profile. Should the youth not fit the runaway profile, then an intensive investigative follow-up may be indicated, as the youth could possibly be a victim of "foul play."

The discriminant analysis divided the subjects into a group of runaways and a comparison group of youths that had not yet run. The analysis was used to find classification functions (linear combinations of the variables) that best separate the groups. These functions are 
useful for classifying new subjects. We used the stepwise discriminant analysis program to find subset variables that maximize group differences. The variables were entered into classification function one at a time until group separation ceased to improve notably. The Wilks' lamda (U statistic) and the F approximation to lamda were printed at each step of the output for testing group differences. This was al]. done through the computer facility at the Regional Institute at portland State University under the direction of Dr. Quentin Clarkson.

$$
\text { PRESENTATION OF DATA }
$$

\section{Highly Significant Discriminators:}

These data reveal fifteen out of a possible forty-three statistically significant discriminators.

\begin{tabular}{|c|c|c|c|c|c|}
\hline $\begin{array}{l}\text { STEP } \\
\text { NUMBER }\end{array}$ & $\begin{array}{l}\text { VARIA BIE } \\
\text { ENTERED }\end{array}$ & $\begin{array}{c}F \\
\text { VALUE }\end{array}$ & $\begin{array}{l}\text { NUMBER OF VARI- } \\
\text { ABLES TNCLNDED }\end{array}$ & $\begin{array}{l}\text { U-STAT- } \\
\text { ISTIC }\end{array}$ & $\begin{array}{l}\text { DIFFERENCE } \\
\text { PERCENTA GE }\end{array}$ \\
\hline 1. & (School problems) & 260.6409 & 1 & 0.3774 & $62 \%$ \\
\hline 2. & (Family stress) & 28.6001 & 2 & 0.3193 & $68 \%$ \\
\hline 3. & $\begin{array}{l}27 \\
\text { (Parent's approval } \\
\text { of sexual attitudes) }\end{array}$ & 15.0113 & 3 & 0.2912 & $71 \%$ \\
\hline 4. & $\begin{array}{l}28 \\
\text { (Parent separation } \\
\text { under } 5 \text { yrs of age) }\end{array}$ & 13.5654 & 4 & 0.2678 & $73 \%$ \\
\hline 5. & $\begin{array}{l}29 \\
\text { (No family members } \\
\text { past munaways) }\end{array}$ & 8.0424 & 5 & 0.2545 & $75 \%$ \\
\hline 6. & $\frac{22}{\text { (Employment status) }}$ & 6.6983 & 6 & 0.2438 & $76 \%$ \\
\hline
\end{tabular}


30

\begin{tabular}{|c|c|c|c|c|c|}
\hline $\begin{array}{l}\text { STEP } \\
\text { INJMBER }\end{array}$ & $\begin{array}{l}\text { VARIABLE } \\
\text { ENTERED }\end{array}$ & $\begin{array}{c}F \\
\text { VALUE }\end{array}$ & $\begin{array}{l}\text { NUMBER OF VARI- } \\
\text { ABLES INCLUDED }\end{array}$ & $\begin{array}{l}\text { U-STAT- } \\
\text { ISTIC }\end{array}$ & $\begin{array}{l}\text { DIFFERENCE } \\
\text { PERCENTA CE }\end{array}$ \\
\hline 7. & $\begin{array}{l}41 \\
\text { (Recent death family } \\
\text { or close friend) }\end{array}$ & 5.0599 & 7 & 0.2360 & $76 \%$ \\
\hline 8. & (Mother \& father $\operatorname{ran}$ ) & 4.4765 & 8 & 0.2292 & $77 \%$ \\
\hline 9. & $\begin{array}{l}13 \\
\text { (History of truancy) }\end{array}$ & 3.7602 & 9 & 0.2236 & $78 \%$ \\
\hline 10. & $\begin{array}{l}42 \\
\text { (Recent family move) }\end{array}$ & 2.8168 & 10 & 0.2194 & $78 \%$ \\
\hline 11. & $\begin{array}{l}40 \\
\text { (Psychiatric problems } \\
\text { a family member) }\end{array}$ & 5.4180 & 11 & 0.2117 & $79 \%$ \\
\hline 12. & $\begin{array}{l}15 \\
\text { (Breaking school } \\
\text { rules) }\end{array}$ & 2.8922 & 12 & 0.2076 & $79 \%$ \\
\hline 13. & $\begin{array}{c}43 \\
\text { (Recent divorce) }\end{array}$ & 2.8545 & 13 & 0.2036 & $80 \%$ \\
\hline 14. & (Status Offenses) & 2.6512 & 14 & 0.2000 & $80 \%$ \\
\hline 15. & (Legall problems) & 1.8659 & 3.5 & 0.1974 & $80 \%$ \\
\hline \multicolumn{6}{|c|}{ Importance of Discriminators: (First five variables) } \\
\hline \multicolumn{6}{|c|}{ Probabilities of Accuracy: The first five variables on the table } \\
\hline
\end{tabular}

Interpretation: If the person reporting the youth missing responds in the following manner: 
1. The child has no school problems.

2. There is no stress in the family.

3. The parent approves of the child's sexual attitudes.

4. There was no prolonged natural parent separation before the child was five years of age.

5. No other members of the family have a history of munning away.

We might assume with $91 \%$ accuracy that the child does not fit the munaway profile and thet further information is necessary to determine whether this is a runaway case or whether it is a case indicating the possibility of "foul play". Should all these questions be answered in the affirmative then there is a 93\% probability that the youth fits the runaway profile. Importance of Discriminators: (First Ten Variables)

Probabilities of Accuracy: The first ten variables on the table (steps one through ten) show a discriminating accuracy probability of $94 \%$ for both groups.

Interpretation: Should the person reporting the youth missing respond that:

1. The child has no school problems.

2. There is no stress in the family.

3. The parent approves of the child's sexual attitudes.

4. There was no prolonged natural parent separation before the child was five years of age.

5. No other members of the family have a history of munning away. 
6. The head of the household is employed.

7. There was no recent death either of a family member or close friend (within the past year).

8. Neither the mother or father ever ran away as youths.

9. The missing youth had no history of truancy.

10. The family has not moved in the past year to a new location involving a school change for the missing youth.

We might then assume with $94 \%$ accuracy that the child does not fit the runaway profile and that further information is necessary to determine whether this is a runaway case or whether it is a case involving the possibility of "foul play". Should all of these questions be answered in the affirmative, there is a $95 \%$ accuracy assumption that the child, fitting the munaway profile, is a runaway and can be immediately classified as such. Importance of Discriminators: (First fifteen variables)

Probabilities of Accuracy: The first fifteen variables on the table (steps one through fifteen) show a discriminating accuracy probability of $95 \%$ for the comparison group of youths that have not run away and a discriminating accuracy probability of $94 \%$ for the runaway group.

Interpretation: Should the person reporting the youth missing report that:

1. The child has no school problems.

2. There is no stress in the family. 
3. The parent approves of the child's sexual attitudes.

4. There was no prolonged separation of a natural parent before the child was five years of age.

5. No other members of the family have ever been munaways.

6. The head of household is employed.

7. There was no recent death either of a family member or close friend (within the past year).

8. Neither the mother or father ever ran away as youths.

9. The missing youth had no history of truancy.

10. The family had not moved in the past year involving a school change for the missing youth.

11. There had been no psychiatric problems in the family in the past year.

12. The child had no history of boing in trouble at school by breaking school rules.

13. There hed been no recent divorce in the family (in the past year).

14. The child had no history of status offenses.

15. The family had no legal problems within the past year. We might then assume with $95 \%$ accuracy that the child does not fit the runaway profile and that further information is necessary to determine whether this is a munaway case or a case involving a possible "foul play" victim.

With indicators that discriminate this strongly between the two groups one would treat a case with all fifteen variables present as a high priority case. 


\section{4}

Summary: Sixty-eight percent of the total difference in the sample groups is found in the first two variables on the table, i.e. school problems and family stress. This makes these two questions high discriminators between the two groups. Beyond that we find the following high predictors:

1. The first five variables on the table are significant with an average of 73 responding in the same manner in the comparison group (non-runaways) with a 91\% predictability, and 74 responding in the same manner in the runaway group giving a 93\% predictability .

2. The first ten variables on the table are especially significant since an average of 75 responded in the samo manner in both the comparis on group and the experimental group giving a $94 \%$ accuracy in predictability in discrimination between the two groups.

3. In the top 15 variables entered there were an average of 76 responding in the same manner in the comparis on group giving a 95\% accuracy in discrimination and an average of 75 responding in the same manner in the runaway group giving a $94 \%$ accuracy in discrimination.

Importance of the Findings

Relative to the Current Body of Knowledge:

1. Results of Parent Information:

A. Age of Parents: The runaway group showed a mean age of 15 years and one month compared to 15 years and six months 
in the comparison group. The mean ages of the parents were significantly older for the comparison group than for the munaway group:

Mother's Age Father's Age

Comparison croup 42 42 Runaway Group $3 I$ 31

Conclusions: The parents of the runaways tended to be 11 years younger than the parents of the average youth that had not run. This verifies the intake worker's Informa I findings that the parents of runaways do not tend to be within the norm of average age groups for parents of adolescents.

B. Residence: This was not statistically significant since there was very little difference between groups. There was a fairly equal spread of those living in a house as opposed to those residing in an apartment in both groups (4lst step).

C. Employment: Unemployment ranked sixth as a discriminator showing a $76 \%$ difference in the two groups when ranked with the other five top variables. This supports the literature. This variable relates specifically to the research mentioned in the article "Reasons for Runaways" (American Journal of Psychiatry) which indicates that income, unemployment and family attitude toward education are relevant factors. 
D. Marital Status: A divorce in the past year was number 13 on the 15 step predictor table. Showing an $80 \%$ difference in the two groups when ranked with the other top 12 variables and the $U$ statistic was compiled. These data reaffirm the results of the lultnomah County manaway study in 1972 by Susan Greor, et. al. revealing that $65 \%$ of their control group of non-munaways were from natural families in which $44 \%$ of the manaway group came from natural families. There was no direct recent research on runaways experiencing a divorce within the past year.

E. Family Constollation: This had little statistical significance and ranked 28 th in the 43 steps.

F. Educational Level: This had little significance ranking 33 rd in the 43 steps.

G. Income Level: This ranked 19 in the 43 steps, and was significant, but was not highly so.

H. Parent's Attitudes Toward Child's Sexual Habits: This was highly significant as a discriminator. I'his variable ranked third as a predictor for the discrimination between the runaway profile and the comparison group of non-runaways. Disapproval of the child's sexual attitudes, along with family stress and school problems accounts for $71 \%$ of the difference in the munay group from the comparison group. This was a successful retesting of the hypothesis stated in the articles in the literature review. It substantiates Hildebrand's research findings 
("Why Runaways Leave Home") showing that girls between the ages of 15 and 17 ran due to poor home environment and sexual problems (pregnancy, a boy friend, or a threatening father). Similar results were found by Robey, t. al. in "The Runaway: A Reaction to ramily Stress.

I. Prolonged Early Separation From a liatural Parent: Prolonged separation from a natural parent before the child was 5 years of age ranked 4 th in the top 1.5 steps accounting for $73 \%$ of the difference in the two groups. This finding supports Foster's research ("Intrapsychic and Environmental Factors in Running Away From Home"). Out of his sample of 100 munaways, 91 had a history of parent-child separation. The most frequently occurring incidence of early separation was of father-child before the child was five years of age. This variable is a high predictor for discrimination.

J. Family Stress: This was highly significant. A response of "no" to the question of whether the family had experienced family stress in the past year accounted for 68\% of the djfference between the two groups when grouped with the variable of no school problems. Family stress was the second step. Under family stress there were significant findings in the following areas: A. Runaway families tended to experience the following 
stresses in the past year.

1. Recent Death (in the family or of a close friend): This vas step number 7, accounting for $76 \%$ of the difference between the two groups when related to the other six top variables.

2. Recent Family Move (within the past year, involving a school change): This variable ranked loth as a discriminator accounting for $78 \%$ of the difference between the two groups when added to the other 9 top variables.

3. Psychiatric Problems (within the past yoar, of a family member): This variable ranked lith as a discriminator, accounting for $79 \%$ of the difference between the two groups when added to the other top ten variables.

4. Recent Divorce (within the past year): This variable ranked 13th, accounting for $80 \%$ of the difference between the two groups when added to the other top 12 variables.

5. Legal Problems: This was variable 15 which accounted for $80 \%$ of the difference when added to the other 14 top variables.

These findings verified the informal observations of officers doing investigative follow-up as well as those of the munawa intake worker Sidney Jones, that the 
family seemed under undue stress at the time the youth was reported missing.

K. Have Other Family Members Run Away as Juventles: Wo asked several combinations to test the family attitude toward running away (sibblings, parents as youth, etc.). We found the fact that both the mother and father had mun as children as high discriminators between the two groups. This variable ranked 8 th as a discriminator and accounted for $77 \%$ of the difference between the two groups when added to the other top 7 variables.

2. Results of Youth Information:

A. Age: The grand mean of the two groups was 15 years and four months. The mean of the comparison group was 15 and six months and the mean of the runaway group was 15 and one month. There were insufficient data on grade in school, however the runaway group tended to be a year behind grade level relative to the comparison group.

B. Social Isolation: None of these questions appeared to be significant as discriminators. We had hypothesized that the child did not get along well with others, had few friends, did not attend church, was not involved in school activities, etc.

C. History of Antisocial Behavior:

1. School Problems: A "no" answer to this question by the comparison group accounted for $62 \%$ of the 
difference between the two groups and was the top discriminator. The runaway group showed a high occurrence in the following school problems:

a. Ilistory of Truancy: This was the 9th top discriminator, accounting for $78 \%$ of the difference when added to the other top 8 vartables.

b. Breaking School Rules: This was the 12th top discriminator accounting for $79 \%$ of the difference between the two groups when added to the other 11 variables.

These data tell us that the runaway tends to have school problems evidenced by breaking school rules and by truancy.

D. Status offenses: A runaway youth would have one status offense recorded as the data was obtained through the Sheriff's Office. These data find that status offenses rank 14 th accounting for $80 \%$ of the differences in the two groups. The findings were:

croup Nean

Minus One Offense

Comparison

Runaway

3 2

These data tell us that even when excluding the one offense that is an automatic discriminator, the runaway group still tends to have two status offenses. This may be due to a history of running away, truancy, incorrigi- 
bility, or minor in possession.

Summary of the Rosearch Findings:

There were fifteen top discriminating variables. It is important to note that though a variable ranked low on the list does not mean that it is not a good discriminator. It just means that given the combination of those variables preceding it, it is not as significant a discriminator as they are. The top two discriminators are school problems, (accounting for $62 \%$ of the difference between the two groups) and family stress (accounting for 68\% of the difference between the two groups when added to the first variable).

I. Under school problems we find a high incidence of truancy and breaking of school rules within the manaw group. These two variables are also high discriminators.

2. Under family stress we find a high incidence of death in the family or of a close friend, a family move involving a school change, unemployment, family psychiatric problems, a recent divorce and legal problems (all within the past year) occurring in statistically significant numbers in the runaway group making these stress variables high discriminators between the two groups.

3. Other important variables were:

A. Parent's attitudes toward the child's sexual habits was the third top discriminator, accounting for $71 \%$ of the difference in the two groups with only the other two top variables added. 
B. Prolonged early separation from a natural parent, before the child was 5 years of age. This was the lith highest variable, accounting for $73 \%$ of the difference between the two groups with only the other three top variables added.

C. No other family members had mun was the fifth highest discriminator, accounting for $75 \%$ of the difference in the two groups when added to the other four variables.

1. In the runaway group, it was found that the mother and father had both run as children in significantly high numbers compared to the comparison group, making the fact of mother and father muning a high discriminator, ranking number 8 and accounting for $77 \%$ of the difference between groups when added to the other top 7 variables.

D. A history of status offenses was the 14 th variable. It is a good discriminator showing the munaway group averaging 3 status offenses as compared to the comparison groun with none.

E. Parental age is a good discriminator with an average of 42 years for the comparison group parents. The average age of the minaway parent group was 30 years. The research findings indicate that out of 43 possible variables on the questionnaire administered to the runaway group and to the comparison group, as few as 15 variables account for $80 \%$ of the 
differentiation between the two groups, with school problems and family stress alone accounting for $68 \%$ of the differentiation between the two groups. 
CHA PTER V

RECORENDATIONS

This research should be viewed as preliminary. The writers believe that these data show good discriminators. This should be further tested with follow-up research. Suggestions for Implementation with Sheriff's Office

A report form could be developed and tested in one team policing area. The other areas would not use the form and at the end cf one year citizens having reported a child missing could be interviewed as to their satisfaction with service provided. A questionnaire could be developed to be administered to this group and to a control group of citizens who have reported a child missing during the same time period but residing in the team area where the report form was not utilized. The tool could be tested in a similar manner with the officers involved in both groups. A case monitoring system indicating the number of hours spent on cases in both groups would be a further indicator of the effectiveness of the tool. At the erid of a year these data should be reviewed and recommendations made 35 to the widespread implementation of tool as a department wide report form and one that might be utilized nationally. Suggested Report Form for Data Collection

The clerk taking the original report should proceed as follows:

1. Age of the child: If the child is under la, thon an officer 
should be dispatched immediately, since children under this age do not fend well for themselves and do not fit the a verage age span of runaways (12-16). 2. Does the child have any history of school problems? A. Yes Answer: Ask type of problem (truancy, drugs, breaking the rules, disruptive behavior, assault, other).

1. If there is truancy and/or breaking the rules then a high likelihood of the child being a runaway exists.

B. No Answer: With this answer there is a high likelihood that the child does not fit the runaway profile and one should ask the following question:

3. Has there been any family stress in the last year, such as, a death in the family or of a close friend, a recent move involving a school change for the missing youth, unemployment, family member receiving counseling help due to psychiatric problems, a divorce and legal problems.

A. Yes Answer: A "yes" answer showing family stress involving any one or all of these is a high indicator that the child fits the runaway profile.

B. No Answer: A "no" answer to both these questions, i.e. that the child has no history of school problems and that the family has experienced no family stress as suggested in the question would warrant immediately 
sending an officer to the home for further investigation to determine the possibility of foul play.

Questioning procedure from this point either by the clerk or by the investigtive officer should follow this discriminating profile. Runaway Profile:

1. Child has school problems, especially tmancy, breaking of the mules.

2. Child has family stress, especially, a recent death of someone close, unemployment, legal problems, divorce, a move involving a school change, psychiatric problems in family.

3. Parents do not approve of child's sexual behavior. This particularly relates to girls and their dating habits.

4. There was an early childhood separation of a natural parent before the child was five years of age (divorce, father in service, etc.).

5. Some other member of the family has run in the past, especially the mother or father.

A "yes" answer to these five questions enables one to assume with 91\% accuracy that the child is a munaway. Any mixture of answers can be checked by asking the next set of highly discriminating variables :

6. The head of household is unemployed.

7. The child has a history of other status offenses (past munaway reports, etc.).

8. The parents tend to be very young to have a child the age 
of the child reported missing.

A "yes" to all these questions including the special areas under family stress and school problems gives one a 95\% accuracy on the assumption that the child is a munaway. A "no" to all of these questions is a direct indicator that an intensive inissing person investigation should take place, moving the case to top priority. 
APPENDIY I 
INTERVIEW SCHEDULE FOR PARENTS

Control Group Runaway sample

Member of family interviewed:

Mother

Father

CHILD INFORMATION:

Age Age when last ran ("O" if N/A) Grade in school Sex:

(1) Male

(2) Female

Previous times runaway: (days) Length of time on run (days)

Longest time ever on the run ("O" if $\mathrm{N} / \mathrm{A}$ )

Reason for running: (0) N/A

(1) Argument with parents

(2) Fight with siblings

(3) Change in marital status of parents

(4) Kicked out of home

(5) Law violation

(6) Peer problems

(7) School problems

(8) Combination of the above

(9) I don't know (Iast time) 
Does ch1ld have any friends who have munaway

(2) No $\quad$ Yes

Can you name 3 of child's close friends

(1) No Yes_ (if yes, names)

COMMUNITY INVOLVEMENT

Church attendance:

(1) $\begin{array}{l}\text { Never } \\ \text { Yearly }\end{array} \quad$ (3) $\left.\begin{array}{l}\text { Monthly } \\ 4\end{array}\right)$ Weekly $=$

Does chlld particlpate in sohool activities:

(1) $\begin{aligned} & \text { No } \\ & \text { Yes }\end{aligned}$
(1) No problems
(5) Drugs
(2) Truant
(6) Other law violations

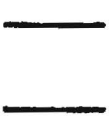
(3) Assault
(8) Combination
(4) Breaking rules

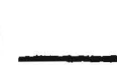

(9) other

FAMILY INFORMATION

Home address is for: (1) Apartment

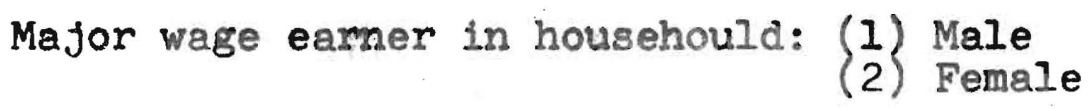

Highest education attaned by head of household:

(1) Post-graduate work

(2) College graduate

(3) Training above high school

(4) High school

(5) Eighth grade

(6) Under elghth grade

Head of household: (1) Unemployed.

(2) Employed

Approximate family income: (1) $\$ 0-\$ 5,000$

(3) $\begin{aligned} & \$ 6,000-\$ 10,000 \\ & \$ 11,000-\$ 15,000\end{aligned}$

$=\left\{\begin{array}{l}4 \\ 5\end{array}\left\{\begin{array}{l}\$ 16,000-\$ 25,000 \\ \text { Over } \$ 25,000\end{array}\right.\right.$

Current family constellation:

(1) Both natural parents

(2) Single parent

(3) Natural mother and step father
(4) Natural father and step

(5) Foster parent

(6) Group home mother 
Parental age: $\left\{\begin{array}{l}1 \\ 2\end{array}\right)$ Mother

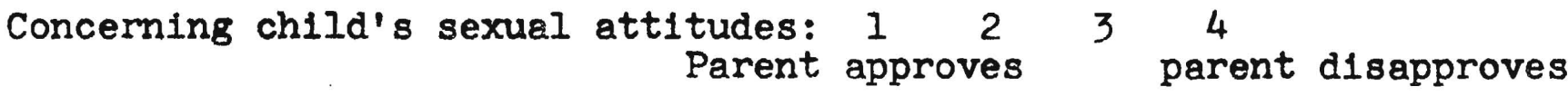

Was there prolonged separation (one month) of natural parent before age 5 years? $\left\{\begin{array}{l}1 \\ 2\end{array}\right)$ No

Have any members of family (other than child under discussion) ever run away as juveniles?
(0) None have
(4) Father, mother and stblings
(I) Mother
(5) Siblings
(2) Father
(6) Mother and siblings
(3) Mother and father
(7) Father and siblings

Family stresses occurring in last year:
(0) None occurred
(6) Family move (involving
(1) Birth
(7) Divorce
(2) Financial problems
(8) Remarriage
(3) Legal problems
(9) Combination
(4) Psychiatric problems
(5) Death of family member or close friend 
APPENDIX II 


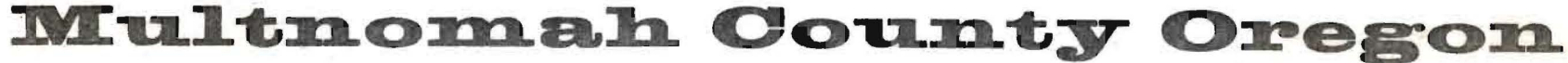 BMERIFF'S OFFICE - DEPARTMENT OF PUBLIC SAFETY}

TO WHOM IT MAY CONCERN:

This will introduce Pat Hoffman, who is engaged in a study on the procedure to report and follow-up runaway and missing juveniles. The end result of this study will be the development of an improved procedure that will enable the Multnomah County, Department of Public Safety, to provide appropriate investigation of these cases. Your honest and complete answers to this questionnaire will provide the datum necessary to improve these services.

I am interested in further improving the services the Department can offer, and since you had a recent occasion to request the services of the Multnomah County Sheriff's Office, you can help me by providing direct and current information. You may be completely assured that your responses will be held in strict confidence, and that your responses will be entered without name identification into the final summary.

I shall appreciate your personal assistance.

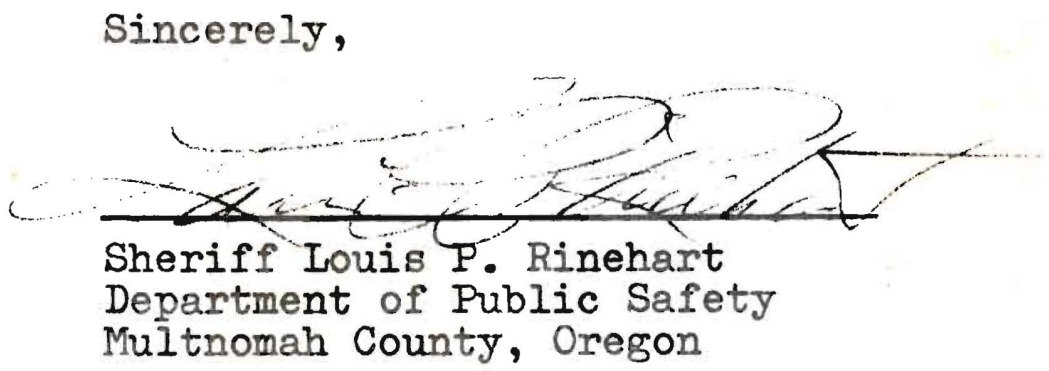

$\mathrm{DB} / \mathrm{lk}$ 


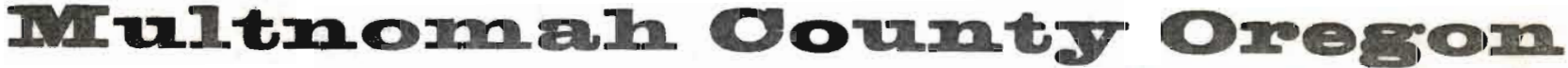 BHEIRIFF' OFFICE = DEPARTMENT OF PUBLIC SAFETY}

(503) 227-8411 $\backsim$ COUNTY COURTHOUSE $=$ PORTLAND, OREGON 97204

TO WHOM IT MAY CONCERN:

This will introduce Neil Crannell, who is engaged in a study on the procedure of reporting and following-up munaway and missing juveniles. The end result of this study will be the development of an improved procedure that will enable the Multnomah County, Department of Public Safety, to provide appropriate investigation of these cases. Your honest and complete answers to this questionnaire will provide the data necessary to improve these services.

You are being asked to participate in the control group of non-runaways, essential to this study. I am interested in improving the services the Department can offer. Your cooperation in this project will greatly facilitate such improvements. You may be completely assured that your responses will be held in strict confidence, and that your responses will be entered without name identification into the final summary.

I shall appreciate your personal assistance.

Sincerely,

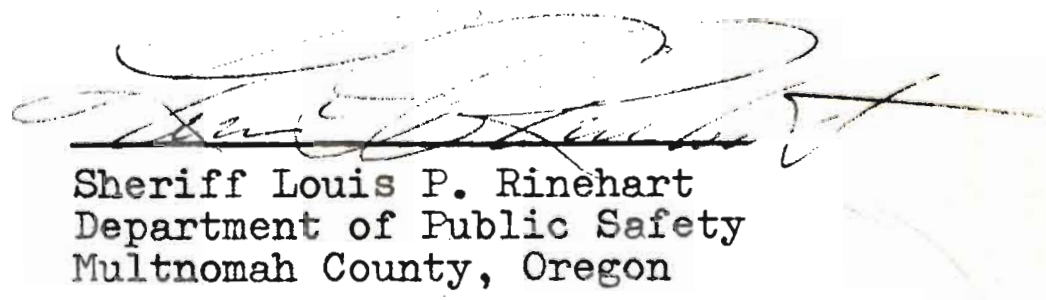

Ik 
FOOTNOTES

${ }^{I}$ Creer, Susan, Sarah Hertlein, Steven Regner, "A Study of the Characteristics of Runaways and Their Families in Two Social Agencies," Masters Project, Portland State University, 1972, p. 3.

2.James A. Hildebrend, "Why Runaways Leave Home," Jourmal of Criminal Law, Criminclogy and Police science, LIV, June 1963, p. ZII.

${ }^{3}$ Clairette Armstrong, "A psychoneurotic Reaction of Delinquent Boys and Girls, "Joumal of Abnormal and Social Psychology, October 1937, pp. 329-42.

4Morris Riemer, "Runaway Children," American Journal of Orthopsychiatry, JuJy 1940, pp. 522-26.

Frederick Rosenheim, Techniques of Therapy, "American Joumal of Orthopsychiatry, JuIy 1940, pp. 651-59.

6G.E. Outland, "Determinants Involved in Boy Transiency, "Journal of Eduostional Sociology, Vol. XI, 1938, pp. 360-72.

7 Benjamin Blaser, "A Behavior Problem--Runaways," The Psychiatric Quartarly, July 1939, pp. 539-57.

8Joseph Paull, "The Runeway Foster Child," Child Welfare, July 1956, pp. $21-26$.

9 Hildebrand, Op. cit. p. 2.11

10 James Hildebrand, "Reasons for Runaways," Amexican Jourmal of Orthopsychiatry, October 1963, pp. 42-48

12

Ibida, p. 47 .

I2 Robert Shellow, Julianna Sohamp, Elliot Liebow and Elizabeth Unger, Suburben Runaways of the 1960's, Chicago: Society for Research in Child Development, 196.? 
13. Ibid., p. 28 .

14 Amos Robey, Richard Rosenwalf, John Snell and Rite Lee, "The Runaway Girl: A Reaction to Family Stress," American J ourmel of Orthopsyohiatry, Vol. XXIV, No. 4, July 1964, pp. 762-767.

15 Ibid., p. 763.

16 Ibid., p. 766 .

17 Randall Foster, "Intrapsychic and Environmental Factors in Running Away From Home, "American Journal of Orthopsychiatry, Vol. XXXII, No. 3, April 1962, pp. 486-91.

$18_{\text {Ib1d., p. } 491 .}$

${ }^{19}$ Jobn Goldmeler and Robert Dean, "The Runaway: Person, Problem or or Situation?" Crime and Delinquency, Vol. IXX, No. 4, October 1973, pp. 539-544.

20 Theod ore Levanthal, "Inner Control Deficiencies in Runaway Children" Archives of Conerel Psychiatry, Vol. II, August 1964, pp. 170-76.

21

Ibid., p. 170

22M.C. Howell, E.B. Emmons, D.A. Frank, "Reminiscences of Runaway Asolescents" American-Journal of Orthopsychiatry, Vol. 43, No. 5, October 1973, pp. 840-853. 
BIBLIOCRA PHIY

Ambrosino, I. Runaways. Boston: Beacon Press, 1971.

Armstrong, C. P. "A Psychoneurotic Reaction of Delinquent Boys and Girls." Journal of Abnormal Social Psychology, 1937, 32 , $(3-4), 329-34,2$

Balser, B. H. "A Behavior Problem - Runaways," Psychiatric Quarterly, 1939, 13, 539-557.

Foster, R. M. "Intrapsychic and Environmental Factors in Running Away from Home." Amorican Joumal of Orthopsychiatry, 1962, 32 (3), 488-491.

Goldmeier, J. and Dean, R. D. "The Runaway: Person, Problem, or Situation?" Crime and Delinquency, 1973, 19 (4), 539-544.

Grer, Susan, Sarah Hertlein, and Stephen Regner. "A Study of the Characteristics of Runaways and Their Families in Two Social Agencles." Unpublished Master's Practicum, Portland State University, Portland, Oregon, 1972.

Hildebrand, J.A. "Reas ons for Runaway." Crime and Delinquency, 1968,14 (I), $42-48$.

Hildebrand, J.A. "Why Runaways Leave Home." Joumal of Criminal Iaw, Criminology, and Police Science, 1963, 54 (2), 211-216.

Howell, M. C., Emmons, E. B. and Frank, D. A. "Reminiscences of Runaway Adolescents." American Joumal of Orthopsychiatry, $1973,43(5), 840-853$.

Jenkins, R. L. "The Runaway Reaction." American Journal of Psychiatry, 1971, 128 (2), 168-173.

Levanthal, Theodore. "Inner Control Deficiencies in Runaway Children." Archives of Ceneral Psychiatry, II, August 1964, 170-176.

Outland, G. E. "Determinants Involvod in Boy Transiency." Journal of Educational Sociology, XI, 1938, 360-372。

Paull, Joseph. "The Runaway Foster Child." Child Welfare, July 1956, 21-26. 
RIemer, M. C. "Runaway Children." American Journal of Orthopsychiatry, $1940,10(3), 522-526$.

Riley, Do "Runaways: And Then There were Thousandso" Delinquency Prevention Reporter, 1972, February, 3-11.

Robey, A. "The Runaway Cirrl." In O. Pollak and A. Friedman (Eds.). Family Dymamics and Female Sexual Delinquency. Palo Alto: Science

Rosenheim, F. "Techniques of Therapy: Symposium on Treatment Presented at the 1940 Heeting." American Joumal of Orthopsychiatry, $1940,10(3), 651-659$.

Shollow, R०, Schemp, J० R., Liebrow, I., and Unger, E. Suburban Runaways of the 1960's. Monographs of the Society of Research 